\title{
New Directions: \\ Privatization and Higher Education in Alberta
}

\section{PETER RAE}

University of Manitoba

\begin{abstract}
Recent Alberta initiatives in higher education reflect a growing Canadian preoccupation with privatization. Opposing ideological forces offer conflicting assessments of privatization in higher education: as endangering the very nature and goals of higher education or as simply providing additional resources and greater consumer choice. Privatization in higher education is identified as a shift in the balances of finance or control from public to private. It is implemented in higher education through the encouragement or toleration of private educational institutions or through the fostering of private investment in public systems. Alberta's 1994 restructuring of postsecondary education is identified as an approach which implements a privatization agenda while claiming to safeguard public interests.
\end{abstract}

\section{Résumé}

Les récentes initiatives albertaines en matière d'enseignment supérieur reflètent la préoccupation croissante des Canadiens à l'égard de la privatisation. Les tenants et les opposants de la privatisation de l'enseignement supérieur voient ces conséquences sous des angles 
différents. Les uns la voient comme offrant tout simplement au consommateur des ressources supplémentaires et un choix plus grand de possibilités, les autres comme mettant en danger la nature même et les buts de l'enseignement supérieur. La privatisation peut se définir par le fait que le financement et la direction de l'enseignement supérieur se déplacent du secteur public vers le secteur privé. Elle se manifeste par l'appui accordé aux établissements privés ou par l'ouverture dont on fait preuve à leur égard, ou encore par le fait d'encourager les sociétés privées à investir dans le système public. La restructuration, en 1994, de l'enseignement postsecondaire en Alberta est vue comme la mise en pratique d'objectifs de privatisation non déclarés, et ce, même si l'on prétend protéger les intérêts du public.

\section{Introduction}

Privatization can be conceptualized as a movement driven by a perception of fiscal crisis, by fear of rising government debt, by talk of tax revolts; fostered by a renewed belief in market forces and a loss of faith in the efficacy of state coordination and government intervention. It is a movement that is trumpeted as promoting choice, responsiveness, and efficiency.

Within higher education privatization is a comet that has yet to reach its zenith. It has been embraced in developing countries as a means of expanding access to higher education by harnessing private resources (Habte, 1986; World Bank, 1994); championed as a way of making higher education more entrepreneurial, competitive, and responsive to the workings of the market (Geiger, 1988; Kerr, 1990); identified as a high road to the diversity which pluralist cultures require (Edwards \& Whitty, 1992, p. 114); and advanced as a kind of medicinal compound which is most efficacious in every case.

Canada has hardly been in the vanguard of this movement. A number of factors can account for this: perhaps because of the strength of the Canadian conviction that the university ought to be both public and autonomous (Jones, 1994, p. 11); perhaps because of the absence of a coordinated, national educational policy; and perhaps because of the 
predilection for order rather than freedom that some would identify as typifying Canadian society and higher education (Skolnik \& Jones, 1992). Indeed, in discussing "International Trends and Issues in Higher Education Policy," Goedegebuure et al., in their analysis of Ontario identified Canada as the only jurisdiction that does not exhibit a marked movement towards privatization (1993).

Privatization, however, can be identified as a growing influence in Canadian higher education in a number of areas. One could point to federal proposals for funding changes, to various provincial initiatives, or to myriad institutional enterprises. This article examines the application of privatization in higher education and considers Alberta's adult learning framework, New Directions for Adult Learning in Alberta, as an implementation of these principles in the Canadian context. First released in October, 1994, the White Paper "sets new directions for adult learning in Alberta" (p. 8) and encapsulates the pragmatic and ideological issues posed by privatization.

\section{Towards a Definition of Privatization}

Privatization is the term popularly applied to the transference of stateowned enterprises into private ownership and control. Such enterprises might be industries once nationalized by government (e.g., mines; telecommunications; insurance), or so-called public services (e.g., health; electricity; transport; water supply; education), delivery systems traditionally assumed to be in the public domain and to be the responsibility of the state (Roth, 1987, p. 25).

But Gormley (1990) suggests that there are many faces to privatization, that it is multiple, not singular, in its approach, implications, and applications. He identifies four main approaches. The most radical application of privatization is, he says, the wholesale selling of assets by "shifting a function entirely out of government, such that government ceases to be the provider or controller of that function" (Butler, 1990, p. 18). A second form involves the contracting out of services where government funds and oversees a function that is then provided by a contractor. A voucher system is a third application of privatization in 
which government provides the recipient of services with earmarked resources to purchase private goods or services. This devolves choice to the consumer and is seen to approximate market conditions. The fourth approach is load-shedding where government simply withdraws all or part of its support for particular services and allows the slack to be picked up (or not) by the private sector.

These approaches (and others like them) indicate the myriad faces of privatization. While some initiatives cede all responsibility and control to the private sector, others affirm governmental oversight and coordination. Curiously then, privatization can lead to less or to more government control: less control when government defers to the market; more control when the government becomes the market and acts as the purchaser of services.

The primary rationale for privatization is economic; divestment of public responsibility for services is seen to reduce government expenditure, since free market competition will, the suggestion goes, create more efficient services and offer better value for money than will a public monopoly. Furthermore, market-oriented enterprises are said to respond more swiftly to the demands of consumers and will promote diversity, giving a greater range of choices than centrally planned systems could offer.

The theoretical underpinnings of privatization are conservative and capitalist. Privatization is extolled most vigorously by those who see the public sector, irredeemably poisoned by self-interest, as promoting economic inefficiency and circumscribing individual autonomy. Privatization is opposed by those who see it as undercutting essential social values; allowing unreliable private operators to control essential public interests; undermining the foundations of liberal democracy by presuming government ineptitude and counseling a rejection of public processes in favour of the market, shrinking the ambit of democratic control. Those inclined to the via media see privatization as a means rather than an end. Since society is a mixed economy where private gain is blended with public good privatization can, at its best, be a potent tool for maximizing social utility and, at its worst, can actually increase costs and undercut primary social values. 
Movements to privatize higher education embrace two discrete objectives. The first is to increase the flow of private resources into higher education. Geiger speaks of "the net addition of private resources for higher education, or the substitution of private resources for public ones" $(1988$, p. 7). The second objective is to make higher education more responsive to the workings of the market: specifically, to respond to the demands of the "consumer" and to serve the needs of economic growth. Thus conceptualized, privatization in higher education might be usefully defined as a shift in the balances of finance or control from public to private (Jones, 1992, p. 1445).

\section{Refining the Focus: Privatization in Higher Education}

\section{Opposing Positions}

Those who oppose the shifts affirm that education is not just a matter of private choice and private good and, consequently, should not be left in the control of private, sectional interests which may be antithetical to the broader public good. Market forces accentuate inequality whether based on wealth, religion, culture, gender, or social class. Higher education ought to be egalitarian, not hierarchical or elitist. In short, those who oppose privatization conceive of a higher education system where vital public interests are embodied in public institutions which are publicly controlled (Bates, 1992, p. 14).

Privatization advocates hold individual freedom to be a primary value and seek an educational system which enshrines that value. The free market is the epitome of choice since its distributive justice responds to the desire of the consumer, seen to be the primary beneficiary of education. Further, public education is depicted as hegemonic which fails to allow for the expressions of difference that a plural society ought to grant; the market, on the other hand, allows for diversity and "distributive and participative justice rather than simple egalitarianism" (Donald, cited in Edwards \& Whitty, 1992, p. 114).

This polarization of opinion is reflected in disagreements about the utility of privatization for higher education. To the claim that it will increase funding by "supplying the marginal increases needed for 
increasing social investment" (Geiger, 1987, p. 115), opponents reply that private funding will, at best, be substitutionary and will likely create an excuse for governments to renege on their responsibilities.

Privatization, it is argued, will make education more sensitive to the needs of the market and economic growth and make academics more responsive to the realities of a production-oriented society. Opponents reply that subordinating academic goals to economic ones will narrow the knowledge base, will threaten the "autonomous functions" (Trow, 1994) of the university, and may even prove economically counter-productive by focusing on short-term returns rather than long-range strategies.

Privatization will allow higher education to become more flexible and diverse, to empower students and to reflect the "growing heterogeneity, fragmentation and difference in modern societies" (Edwards \& Whitty, 1992, p. 112). Critics reply that such diversity is sectarian and divisive, "a class strategy that has as one of its major effects the reproduction of relative social class" (Ball, quoted in Bates, 1992, p. 6). Institutions, they contend, will become malleable, not flexible, and will be molded to meet the interests of the already advantaged.

To the claim that privatization will increase efficiency through lower costs and higher completion rates (Habte, 1986, p. 2), opponents observe that efficiency is a much more complex issue than mere unit cost per student; it also involves academic, social, moral, and aesthetic issues, so performance indicators are "at best indirectly related to the central work of universities" (Bruneau \& Savage, 1995, p. 3). Nor is it clear that privatization will increase competition or decrease public investment; Butler, using the US as an example, observes that what passes for privatization "may be a way, in fact, of securing and expanding government investment" (1990, p. 23).

And when proponents affirm that equity would be enhanced by forcing the user to pay (since subsidized tuition is a socially regressive reverse income transfer) dissenters reply that higher fees would reinforce the economic hierarchy, that even generous loan repayment schemes would intimidate the disadvantaged who fear the spiral of debt.

These differences stem from inherent conflict over the basic objectives of education. One view sees the primary values of education as 
social to which economic values are subordinated. The opposing view sees economic goals as primary with the production of wealth being a prerequisite for the existence of more esoteric values. Holding these values as complementary, Lawton and Tzalalis suggest, is a difficult task and they conclude that "the apparent ascendance of economic goals for education in the present decades must give us pause" (1994, p. 13).

\section{The Means}

The two objectives of privatization noted above (shifting the balances of finance and control) link neatly to two means identified by Levy (1992) by which privatization is implemented in higher education: through the growth of private institutions and through the growth of private funding sources.

International literature suggests that growth and diversity in the higher education sector can be achieved by tolerating or encouraging the establishment of private institutions. This can be seen as a kind of 'deregulation,' removing a public monopoly to allow the development of a private sector. As a recent World Bank report stated, "private institutions ... can respond efficiently and flexibly to changing demand, and they increase educational opportunities with little or no additional public cost" (1994, p. 5). Private institutions, then, can provide more or distinct educational opportunities.

The distinction between private and public institutions is far from clear as the literature on the subject reveals. Geiger suggests that private institutions have "the ability to pursue their own goals" (1991, p. 233). Kerr (1990) argues for multiple dimensions of privateness: ownership; control; and finance (source and distributive control). Levy offers a profile of privateness based on several continua: finance, control, and mission (1986). In Canada, the term is used in two different ways. It is occasionally employed by public universities to assert their autonomy from Government (Ontario Universities, for instance, often refer to themselves as private). It is also used to identify institutions that are private for profit (for example, private vocational institutions) or private for principle (institutions which serve a distinct private constituency, often 
religious or cultural). It is institutions which are private in this second sense which, in Canada, are attractive to the privatization lobby.

There are three primary sources of private funding for higher education: user fees, philanthropic contributions, and entrepreneurial activities. Maximizing these is the second means by which the goals of privatization are addressed.

Tuition fees are the most common form of cost recovery and increasing such fees is one means of increasing the proportion of funds stemming from private sources. In many countries, tertiary education has been provided at negligible cost to the student; in all systems, the public purse subsidizes higher education (World Bank, 1994, p. 23). Even private institutions often depend heavily on direct or indirect state support. Privatization, then, could involve passing on some, more, or all of the costs of higher education to the student, the student's family, or the employer. This is a form of load shedding, as government passes the burden of funding on to the user. The imposition of fees is justified on the basis that students and employers realize significant private benefit from higher education and ought to pay for that benefit since they are the primary users or consumers of higher education.

The ostensible benefits of fee recovery include increased revenue for the institution or, at least, a diversification of funding source which would allow greater institutional flexibility and autonomy; an increased stake in the process by the student who would then be more inclined to make greater use of educational opportunities; and greater efficiency through competition, as institutions compete for students. The drawback of fee recovery is in the realm of equity. It would seem to affect adversely those least able to pay and, thus, make higher education even less reflective of society at large and even more weighted towards those who are already economically advantaged. However, since present schemes of low tuition already favour the advantaged (who are disproportionately represented in PSE), an increase in fees coupled with enhanced grant or bursary schemes and access programs aimed at the disadvantaged could actually make the system more equitable and less regressive (Levin, 1990; World Bank, 1994). 
Philanthropy is a second source of private income. Societies with mass public systems of higher education tend to have a low pattern of voluntary donations as the state is seen to be the provider of welfare services. Where nations seek to revise this perception of public responsibility one strategy is to raise the consciousness level of generous donors: charitable foundations, alumni, boosters of a local institution, or those sympathetic to the particular orientation of an institution. Such contributions are typically seen to be altruistic and not motivated by the expected return that drives partnerships with industry. Favourable tax laws are a means of generating a climate which nurtures philanthropy and act as an indirect subsidy to charitable organizations.

As well as offering plural funding sources the mobilization of private donors can change the balance of control by providing a potent political influence and buffer against government encroachment or, as Jones observes, a formidable political force (often conservative) within the institution itself (1992, p. 1449).

Entrepreneurial activities are a third means by which institutions increase income from private sources and become more responsive to the needs of the market. Institutions may undertake contracted research projects or training programs; supply consultancy expertise; establish hybrid or co-operative programs; and/or establish spin-off companies or industrial parks to purvey their own products. Institutional administration and employment practices become more managerial since such approaches facilitate entrepreneurial activities more readily than traditional collegial forms which may therefore be marginalized (Newson, 1994).

The critiques of such entrepreneurial activity suggest that what seems to be in the interests of the market may not prove to be in the best interests, long or short term, of society as a whole. Without doubt, however, the political zeitgeist seeks to couple investment in higher education with economic growth and so privatization becomes the means both to channel additional resources from industry into higher education and to make higher education more sensitive to market needs by adjusting the balances of finance and control. 


\section{The Application: New Directions.}

Alberta's Conservative government has implemented a broad range of privatization measures. It has privatized provincial liquor stores; introduced user fees into provincial health care and early childhood education systems; moved to privatize parts of the hospital and prison systems (through contracting out food services) and some public transportation services; and has opted for load shedding in social service areas and in welfare services. These initiatives suggest a belief in the invisible hand of market forces for forwarding the common good and a vision of competitive capitalism as the means to greater choice, responsiveness, and efficiency than supplied by state bureaucracy. The Progressive Conservatives, following the lead of Premier Ralph Klein, have asserted that "less government is better government" (Bergman, 1994) and other jurisdictions, both provincial and federal, are watching the Alberta experiment closely.

Higher education has also been pushed in the direction of privatization. The goals for higher education are identified as follows by the Department of Adult Education in its New Directions framework: to be affordable, "providing quality learning opportunities...at the lowest possible cost"; to be accountable "to Albertans for the results of publicly funded learning opportunities"; to be accessible, offering "a diverse range of quality learning opportunities"; and to be responsive "to the needs of the individual learner and to the social, economic and cultural needs of the province". Privatization's twin objectives of fiscal efficiency and market relevance can clearly be recognized in such goals. The document includes under the rubric of adult learning all formal educational opportunities for adults: basic education and skills training; career and technical programs; and higher degree programs, both undergraduate and post-graduate. It is perhaps significant that higher education is subsumed under the broader heading of adult learning; the autonomous nature of the former is assimilated by the more instrumental nature of the latter.

Of the 22 strategies proposed in the document at least 14 embody an implicit appeal to the tenets of privatization. While privatization is not 
explicitly identified as such in the document, four privatization themes are clearly discernible: private providers will be encouraged; users will pay more; competition and accountability will be maximized; and articulation with industry will be accentuated.

\section{Private Provision}

New Directions can be seen to encourage the private provider of post secondary education. This is consistent with earlier Alberta policy, notably the establishment of the Private Colleges Accreditation Board (PCAB) in 1984, which made Alberta the only province with a formal process for accrediting private degree-granting institutions. New Directions does not directly endorse private higher education but, rather, throughout its fabric presupposes their existence and addresses their concerns in the following sections of the document.

Section 1.1, which introduces the \$47-million Access Fund designed to promote "innovative, cost-effective methods of increasing accessibility," speaks of competition for resources between public and private providers. Private providers with more flexible staffing structures and program arrangements are well positioned to compete with large public institutions that are locked into collective bargaining agreements and complex departmental political structures. (Indeed, several private colleges have been awarded substantial amounts from the fund);

Section 1.4 recognizes the role of private providers in offering "alternate routes to employability," and encourages the growth of private vocational institutions which offer educational opportunities outside the traditional post-secondary sphere. It reaffirms the Government's commitment to the Skills Canada program, which underscores the role of proprietary colleges;

Section 2.6 seeks to improve the articulation of course transfers between institutions noting that "the department will hold the boards of public post-secondary institutions individually and collectively accountable for the further development of transfer arrangements and the elimination of difficulties to transfer courses between institutions." While this addresses the concerns of the broader non-university sector, it is of 
particular interest to many private providers who see the value of their academic currency rising;

Sections 4.1. and 4.2 further systematize the processes for accountability and accreditation of private institutions, adding to the infrastructure established through the PCAB; and Sections 3.1 and 3.2 which propose raising tuition and enhancing students assistance (through income sensitive loans and loan remission) are perhaps most important as they comprise an indirect subsidy to the private sector which depends on tuition income (underwritten by student loans) for survival.

New Directions offers financial aid, academic recognition and political support to private providers of education. It is a document that continues to nurture and encourage private institutions. The public universities find their monopoly broken and now must compete for resources that were previously earmarked as their own. In a Canada that has long assumed higher education to be public in character (Leslie, 1980 , p. 64), the document sounds a discordant note.

\section{Users Pay More}

New Directions marks a "shifting of emphasis in social policy," as "selfsufficiency and reduced dependence on social support programs are high priority" (Section 5). The intent of the policy shift is that "learners in public post-secondary institutions should pay a greater proportion of the costs of providing opportunities to learn" (Section 3.1). That is, it should reduce the proportion of government contributions to higher education which is a key tenet of privatization.

The document offers the following details: the proportion of "operating expenses paid by students through fees for instruction will be allowed to rise to a maximum of $30 \%$ by the year 2000 " (Section 3.1) By comparison, in 1980 fees constituted $9.3 \%$ of total income at Canadian Universities and 13\% in 1991-92 (AUCC, 1993). In addition, "foreign students will pay at a minimum double the tuition fee assessed to domestic students." To mitigate these measures, "institutions will consult annually with students and will be held accountable to students for the level set for student fees and for the services provided." In other words, students are to become more discriminating and influential clients; however, 
if the dominant issues (fee levels) are predetermined by government fiat it is difficult to see a constructive role in setting the agenda.

The effects of such a measure on access are to be offset by changes in student assistance which "will be annually adjusted in response to changes in tuition fees" (Section 3.2). A remission program, an income sensitive loan repayment plan, and an interest relief program are offered as mechanisms of debt control. These adjustments to student assistance, coupled with increased tuition, suggest that such a plan becomes a modified voucher system giving students portable collateral rather than funding institutions directly. The extensive literature on educational vouchers suggests, amongst other things, that such a process should heighten competition and consumer choice, and act as a subsidy to private education. Rather than being a marginal income source tuition will become pivotal and, thus, institutions will compete more aggressively for students.

Devolving costs to students is not just attractive to Alberta; the 1994 Federal review of social programs (Agenda: Jobs and Growth, 1994) reflected the same preoccupation and other provinces have mused aloud about similar schemes. Indeed, Stager notes repeated reports which have suggested that tuition ought to compose $25 \%$ to $35 \%$ of program operating costs (1989, pp. 81-82). Alberta, however, is moving from discussion to implementation.

\section{Competition and Accountability}

The government seeks to heighten competition through privatization and sees the mechanism of the market as the optimum means to this end. While increased competition is a side effect of Alberta's user-pay schemes, it is a more direct aim of "a new funding mechanism ... that rewards an institution's performance in providing accessibility, quality and relevance to the needs of the learner at the lowest possible cost" (Section 3.3), and at the same time "results must be determined, indicators of performance developed, and performance data defined and collected" (Section 3.2). Performance indicators (PIs) underline the attempt to create quasi-market conditions within the public sector by encouraging competition. Competition is, of course, intended to improve the efficiency and effectiveness of institutions by making them leaner and more 
task oriented. PIs also, under the rubric of accountability, facilitate greater government control.

The accountability framework as outlined in Sections 2.7, 4.1 and 4.2 "will include results expected, and a core set of qualitative and quantitative performance indicators to evaluate an institution's success in meeting those results. These indicators will be published by providers in calendars, annual reports or business plans as appropriate" (Section 4.1), and will, no doubt, be used by users and by government alike. This accountability framework released in February 1995, is output-oriented, measures unit costs (per student and per graduate), program completion rates, and client satisfaction ratings.

Competition is intended to increase choice and reduce cost. It will, however, have its limitations. Presumably, it will exist at entry level but is less likely to be a factor in capital-intensive disciplines. Further, it will prove difficult to reach consensus on what is being assessed by such "competition": whether unit costs, outputs, student experiences, and quality or quantity of teaching and research. The difficulty of establishing quantifiable educational goals suggests that competition may operate only at the lowest common denominator.

Accountability through performance indicators is a growth industry; provinces such as Ontario, New Brunswick, and Newfoundland see them as a means to maximize the social utility of education. But as Bruneau and Savage comment, "behind PIs, then, is accountability as control" (1995, p. 9).

While New Directions does not include a review of research, a discussion paper issued in March, 1995, suggests that accountability is to be heightened. "There is a demand to improve accountability, focusing more on the results of public investments. Hence, there is a growing need to communicate value for public investment. Currently, Advanced Education and Career Development in conjunction with the universities, is working on the development of key performance indicators in the research area (Section 9)". These PIs might well be a means by which government control is maximized. The discussion paper on research concludes with the observation that "the role of Advanced Education and Career Development should not be underestimated as it is the largest 
single financial contributor to university research in Alberta," thus suggesting that the "largely passive attitude" it has previously adopted is about to be replaced with a more engaged approach, implying increased departmental control over an area which heretofore enjoyed significant autonomy and self-determination.

\section{Articulation with Industry}

Given privatization's preoccupation with economic relevance, one might anticipate that such a thread would stitch Alberta's policy together. While the needs of the economy are clearly addressed, the draft document's bald enunciation that adult learning should "Focus on programs that address the needs of the economy," was not carried into the final document due to concerns voiced by respondents that "the focus on the labour market was too narrow and ignored or reduced the value of a general education" (Keeping You Informed, 1994). As a result, the explicit recommendations for coupling adult education more closely to industry are limited.

The pattern of increased articulation with industry is evident, however, in the introduction of a new applied degree, designed to help colleges and institutes "maintain their relevance to the economy by offering more in-depth programs that included significant work experience components" (Section 2.2). This is to ensure that "knowledge and skill competencies identified by employers are met." While this focuses on the non-university sector, the mandate of the Alberta Council on Admissions and Transfer (ACAT) is extended to "review possible ways of recognizing prior learning and work experience as credit toward a credential" (Section 2.6) at all levels as a means of operationalizing adult learning.

New Directions also establishes consultation procedures to include "students, faculty, business and post-secondary institutions along with other Albertans" to "ensure the adult learning system is responsive to the needs of Albertans" (Section 2.3). This is another means to accountability and seeks to make post secondary education more tightly coupled to the needs of the broader community with business identified as a key constituent. Similarly, the intent to evaluate post-secondary programs on the basis of the "competencies and learning objectives" they produce 
(Section 2.7) suggests the importance placed on outcomes and marketable skills.

It is under the rubric of economic relevance that academic tenure is scrutinized: in order for institutions to be able to respond to "fiscal restraints, new programs, program rationalization and reorganization," they need to reexamine collective agreements which "place inappropriate barriers to termination of employment for reasons of fiscal stringency and redundancy" (Section 3.4). In short, the restrictiveness of tenure needs to be dispensed with so that institutions can respond more appropriately to the forces of change. If competition is to be maximized and the entrepreneurial vision realized, then universities and colleges to be able to compete in the marketplace need to be able to release employees if their abilities are surplus to requirements. This also reflects the growing managerialism that is replacing collegial, academic decision making processes. The latter may be more democratic but infinitely less efficient for institutional flexibility.

The exclusion of references to the university's research function from the New Directions document perhaps explains the relatively few explicit allusions to the industry-education axis. Section 2.4 notes that a new framework for university research will be developed in 1995 which will "recognize the significant relationship between the advancement of knowledge and Alberta's economy and quality of life." This has yet to appear but a discussion paper was issued in March, 1995. While by no means establishing government policy, the paper suggests the following comprehensive goal for a university research policy:

To foster and preserve university research that is:

1) of high quality;

2) responsive; and

3) accountable

... within available resources" (Section 3).

"High quality" is a motherhood characteristic: who would speak against it? The other elements of the goal statement seem to accentuate applied rather than foundational research, particularly since the paper identifies as one of the most important factors affecting university research "the increasing emphasis on research and development in 
terms of its contribution to economic and social development" (Section 1). The goal of responsiveness suggests that "for universities to justify their high costs, the focus of their research should be more relevant and responsive to community and provincial priorities and needs." Such relevance is to be reinforced by the heightened accountability noted above. This will, implicitly, constrict the role of research in disciplines which have little correlation with the direct needs of the market or which find it difficult to articulate their disciplinary priorities in terms that seem relevant to narrowly-conceived, economically-weighted, articulations of the public interest.

\section{Conclusions}

The move towards privatization in Alberta offers a useful example of the applications and implications of the privatization debate in Canada. Privatization in higher education adjusts the balances of finance or control from public to private and, in a nation where higher education is conceived of as both public and autonomous, such a movement constitutes a significant volte face.

Since the roots of privatization are found in conservative economic theory which seeks to extend the role of market forces, it finds fertile soil in the political loam of Alberta's Progressive Conservative government. In addition, its support is augmented by a broader concern with public fiscal restraint and a contemporary disaffection with state bureaucracy.

The recent reconceptualisation of adult learning contained in the Alberta White Paper addresses the privatization agenda; it encourages the growth of private institutions (both profit and non-profit) and seeks to implement policies that will increase private investment in education and make the sector more responsive to market forces, a market in which government itself is a key consumer.

One might speculate on the consequent changes effected by this White Paper:

- increasing the proportion of operating costs paid by the student and increasing student debt; 
- increasing the number of private post-secondary institutions and increasing indirect subsidies to such institutions through student loans;

- requiring institutions to meet externally established, quantifiable, evaluative procedures, thus increasing competitive funding procedures;

- reducing low demand programming;

- phasing out tenure guarantees; and

- linking research funding that is linked to market relevance.

Many of these changes are presently being implemented: University grants have been reduced and re-routed in recent budgets, competitive funding policies put into place, and student fees allowed to rise. The scope of the present paper does not permit a closer analysis of the outcomes of the Alberta experiment but a systematic research study to gauge the effects of these privatization initiatives would be most instructive and might help determine which ideological scenario is, in fact, played out in the province.

Whether other Canadian jurisdictions will follow the lead of Alberta is uncertain. The new Ontario government has already indicated its intention to examine its post-secondary policies; yet several other provinces (British Columbia, for instance) seem unmoved. The Federal examination of PSE, included in Lloyd Axworthy's ill-fated Social Security review, proposed a user-pay scheme funded by income contingent loans. It is evident that the issues faced by Alberta as it seeks to reduce the burden of public funding to higher education and to maximize the responsiveness of higher education are precisely those issues that have been confronted internationally both by industrial and developing nations. These are issues which force us to examine once again the purposes of education, to revisit the ideology of the academy, and to ask who will shape the academic futures of our higher education systems. 


\section{References}

Alberta Private Colleges Accreditation Board. (1991). Accreditation handbook. 3rd edition. Edmonton, Alberta.

Alberta Advanced Education and Career Development. (1993). Keeping you informed. Edmonton, Alberta (Fall).

Alberta Advanced Education and Career Development. (1994). New directions for adult learning in Alberta. Edmonton. Alberta (October).

Association of Universities and Colleges of Canada. (1991). Trends: The Canadian university in profile: 1990. Ottawa, Ontario.

Bates, R. (1992). Educational reform: Its role in the economic destruction of society. Keynote Address, AARE/NZARE Conference, Geelong.

Bergman, B. (1994). Ralph's Way. Maclean's, March 7, pp. 18-22.

Bruneau, W., \& Savage, D.C. (1995). Not a magic bullet: Performance indicators in theory and practice. Paper presented at Canadian Society for the Study of Higher Education, June, Montreal, Quebec.

Butler, S. (1990). Privatization for public purposes. In W. Gormley (Ed.), Privatization and its alternatives, (pp. 17-24). Madison, WI: University of Wisconsin Press.

Edwards, T., \& Whitty, G. (1992). Parental choice and educational reform in Britain and the United States. British Journal of Educational Studies, 40(2), 101-117.

Flew, A. (1987). Power to the parents. London: Sherwood Press.

Friedman, M. (1962). Capitalism and freedom. Chicago IL: University of Chicago Press.

Geiger, R.L. (1988). Conference report: Privatization of higher education. Princeton: International Council for Education.

Geiger, R.L. (1991). Private higher education. In Phillip Altbach (Ed.), International higher education: An encyclopedia. Vol 1. New York: Garland Geiger, R.L. (1987). Private initiatives in higher rducation. In D.R. Jones \& J. Anwyl (Eds.), Privatising higher education: A new Australian issue. Melbourne: Centre for Study of Higher Education.

Goedegebuure, L. et al. (1993). Higher education policy: An international comparative perspective. Oxford: Pergamon Press.

Gormley, W.T. (1990). The privatization controversy. In W. Gormley (Ed.), Privatization and its alternatives, (pp. 3-15). Madison, WI: University of Wisconsin Press. 
Government of Canada. (1994). Improving social security in Canada. Ottawa: Human Resources Development.

Gregor, A.D. (1994). The universities of Canada. Commonwealth Universities Yearbook, 1994. London: The Association of Commonwealth Universities.

Habte, A. (1986). Private financing and higher education in developing countries: Towards efficiency and equity. Financing education in developing countries: An exploration of policy options. Washington: ICED Privatization Conference Paper.

Jones, D.R. (1992). Privatization. In B.R. Clark \& G. Neave (Eds.), The encyclopedia of higher education, (pp. 1445-1453). Oxford: Pergamon Press.

Jones, D.R., \& Anwyl, J. (1987). Privatising higher education: A new Australian issue. Melboume: Centre for Study of Higher Education.

Jones, G.A. (1994). The idea of the Canadian university. Paper presented at the Conference on the University, St. John's College, University of Manitoba.

Karmel, P. (1987). Private initiatives in higher rducation. In D.R. Jones \& J. Anwyl (Eds.), Privatising higher education: A new Australian issue, (pp. 1-11). Melbourne: Centre for Study of Higher Education.

Kerr, C. (1987). Higher education in the U.S.: Public, private, and privatized. In D.R. Jones \& J. Anwyl (Eds.), Privatising higher education: A new Australian issue, (pp. 103-117). Melbourne: Centre for Study of Higher Education.

Kerr, C. (1990). The American mixture. Higher Education, 19(1), 1-19.

Lawton, S., \& Tzalalis, T. (1994). The social and economic goals of education. A dichotomy? Education Canada, Spring, 30-33.

Leslie, P.M. (1980). Canadian universities 1980 and beyond. Ottawa: AUCC.

Levin, B. (1990). Tuition fees and university accessibility. Canadian Public Policy, 16(1), 51-59.

Levy, D.C. (1986). "Private" and "public": Analysis amid ambiguity in higher education. In D.C. Levy (Ed.), Private education, (pp. 170-192). New York: Oxford University Press.

Levy, D.C. (1992). Private institutions of higher education. In B.R. Clark \& G. Neave (Eds.), The encyclopedia of higher education, (pp. 1183-1195). Oxford: Pergamon Press.

Newson, J. (1994). Subordinating democracy: The effects of fiscal retrenchment and university-business partnerships on knowledge creation and knowledge dissemination in universities. Higher Education, 27, 141-161.

O'Hear, A. (1991). Education and democracy. London: Claridge Press. 
Roth, G. (1987). The private provision of public services. Oxford: OUP.

Skolnik, M.L., \& Jones, G.A. (1992). A comparative analysis of arrangements for state coordination of higher education in Canada and the United States. Journal of Higher Education, 63(2).

Skolnik, M.L. (1992). Higher education systems in Canada. In A.D. Gregor \& G. Jasmin (Eds.), Higher education in Canada, (pp. 15-25). Canada: Dept. of the Secretary of State.

Skolnik, M.L. (1995). Upsetting the balance. Paper presented at CSSHE Conference, Montreal, Quebec.

Stager, D.A.A. (1989). Focus on fees. Toronto: Council of Ontario Universities. Starr, P. (1990). The case for skepticism. In W. Gormley (Ed.), Privatization and its alternatives, (pp. 25-37). Madison, Wisconsin: University of Wisconsin Press.

Trow, M. (1994). Managerialism and the academic profession: The case of England. Higher Education Policy, 7(2), 11-18.

Universities Act. (1992). Province of Alberta: Edmonton.

Walford, G. (1988). The privatisation of British higher education. European Journal of Education, 23 (1-2), 47-64.

World Bank. (1994). Higher education: The lessons of experience. Washington: World Bank. 